\title{
Isolation and Identification of Uterine Microorganisms in Postpartum Dairy Cows
}

\author{
Azizunnesa $^{1 *}$, S D Joy ${ }^{1}$ and M. O Faruk ${ }^{2}$ \\ ${ }^{1}$ Azizunnesa, Assistant Professor, Department of Medicine and Surgery, Chittagong Veterinary and Animal Sciences University (CVASU), ${ }^{1}$ Sudip \\ Debnath Joy, MS student, Department of Medicine and Surgery, CVASU and ${ }^{2}$ Mohammad Omer Faruk, Veterinary Surgeon, Hathazari, Chittagong, \\ Department of Livestock, Bangladesh
}

(Received 3 January 2011; Accepted 20 August. 2011)

\begin{abstract}
The aim of this study was to isolate and identify uterine microorganisms in postpartum cows and to observe the occurrence of uterine infection in crossbred and local cows. One hundred and nine samples, from both crossbred and local dairy cows were collected from Chittagong area. They were inseminated artificially $(n=89)$ and naturally $(n=20)$. Samples were collected at least 3 months after calving. Among the selected cows, 33 had different reproductive diseases and the rest were from apparently healthy cows. The crossbred dairy cows were more susceptible to reproductive diseases $(19.27 \%)$ than the local ones. Uterine infection was higher $(52 \%)$ in cows inseminated artificially than that of natural ones $(\mathbf{2 1 . 2 1 \% )}$. Nineteen different types of bacteria were isolated from both diseased and healthy animals, except Clostridium spp and Nocardia spp which were not found in diseased animal. Likewise, Bacillus spp and Salmonella spp were absent in healthy animals. Most prevalent bacteria in diseased animal were Staphylococcus spp and Streptococcus spp found in 33\% and $\mathbf{2 7 . 3 \%}$ of the cases respectively. In non-diseased cases, the highest number of samples was positive for Bacteroied spp (13.2\%) followed by Streptococcus spp (10.4\%). On average, the highest number of bacterial population was isolated from diseased samples and most of those bacteria are pathogenic.
\end{abstract}

Key words: Uterine infection, Identification, Postpartum, Dairy cows

\section{Introduction}

Uterine infection is a major problem in reproductive management and inefficient estrous detection. The bovine uterus is sterile before calving and the cervix provides a barrier against intrauterine invasion by pathogens during gestation ${ }^{1}$. Following calving, the uterus may become infected due to presence of infectious or non-specific microorganisms. Several bacterial, protozoan, viral and mycoplasmal infections are common in postpartum period. The most common and economically important bacteria for uterine infection are Actinomyces spp, Escherichia coli, Fusobacterium spp, Pasteurella spp, Pseudomonas spp, and Staphylococcus spp ${ }^{2}$. Cows with uterine infection in the postpartum period generally have lower conception rates at subsequent breeding. A high percentage of cows have bacteria present in the uterus during the first two weeks after calving may be considered as infected. However, by two months post-calving, the prevalence of uterine infection decline to less than 10 percent. Even though, pathogenic bacteria persist in some cows causing uterine disease by preventing physiological uterine involution resulting in sub-fertility in individual cows or even in the whole herds ${ }^{3}$. Bovine genital infections, either specific or non-specific in nature, account for large number of pregnancy failure in cows ${ }^{4}$. Generally, non- specific infection of the genitalia is considered to be the main cause of repeated conception failure ${ }^{5,6}$. Bacterial infection is the most important among the various causes of endometeritis ${ }^{7}$. Such a condition may cause cervicitis or endometritis of various degrees, which may lead to embryonic death and repeat breeding problems ${ }^{8}$. These infections affect fertility by altering the uterine environment resulting in sperm transport impairment, sperm death and hostile environment to subsequent development and maintenance of the conceptus leading to their death ${ }^{9}$. Incidence of uterine infection in cattle decreases with the increasing of the postpartum period, ranging from $90 \%$ in 25 days of calving to postpartum to $9 \%$ in $46-60$ days of postpartum period ${ }^{10}$.

Although, Bangladesh has a good number of cattle populations, however, there is still no treatment strategy against reproductive diseases. Most of the cattle owners in Bangladesh are not solvent economically. Therefore, any damage of their highly priced animal even after treatment of uterine diseases and sub-fertility or death is a serious burden for them. The reason behind this could be lack of skill to diagnose uterine infection properly and nonspecific treatments. Identification of uterine microorganisms and selection of effective drugs could be a good reproductive management in cow. Considering the above facts, therefore, the present piece of research was conducted to know the occurrence 
of uterine infection in dairy cows and to identify the common bacterial population associated with uterine infection in cows.

\section{Materials and Methods}

The research was conducted in the Department of Medicine and Surgery, Chittagong Veterinary and Animal Sciences University (CVASU), Khulshi, Chittagong during the period from June, 2009 to December, 2009. The animals were selected from Chittagong metropolitan area. A total of $109(\mathrm{n}=109)$ cows including both crossbred $(n=66)$ and local $(n=43)$ were selected which crossed a minimum period of three months after parturition. They were in between 2 and 8.5 years of age, categorized as 7-8.5, 5-6 and 2-4 years old. The studied cows were also categorized according to parity. They were in different parity from $1^{\text {st }}$ to $3^{\text {rd }}$ and few cows were more than $3^{\text {rd }}$ parity. The animal inventory is presented in the Table 1.

A questionnaire was prepared and used to record information on age at birth, breed, parity, current physiological status and reproductive performance, recent major clinical illness, last calving date, nature of calving, insemination date and nature of insemination, diseases and treatment. Information in this study was recorded by face to face interviewing the owner and from the individual animal card, routine clinical case register, breeding register maintained at the dairy farm, record book of Artificial Insemination center etc. Clinical examination was also done to identify any abnormalities of cows.

\section{Management}

The cows were kept under traditional management systems. The housing was open or semi-intensive for most of the local cows. Some crossbred cows were reared in the intensive farming system. Both stall and group feeding were practiced round the year. The local cows were supplied with straw, roadside grass, bran and ad libitum water twice or thrice a day. Approximately, $8-10 \mathrm{~kg}$ roughage and $1.5-2 \mathrm{~kg}$ concentrate were provided to crossbred cows twice daily with free access to drinking water. Hand milking was practiced twice a day

\section{Clinical examination}

Prior to collection of samples, each cow was examined clinically. Body conformation, posture and gate, mucous membrane, respiration rate, pulse rate, temperature and any abnormalities, if present, were taken for each cow. Finally, thorough rectal palpation was done to detect estrus and disease conditions of the cows.

\section{Uterine sample collection}

Before collection of transcervical uterine sample, the perineal region of the cows were washed and cleaned properly with fresh water and potassium permanganate solution. Left handed rectal palpation was performed to collect uterine sample by using AI tube. A $10 \mathrm{ml}$ syringe adjusted behind the glass made AI tube with rubber pipe was introduced into the uterus through cervix guided by rectal palpation. The collected sample was transferred to the vaccuotainer tube containing phosphate buffer saline (PBS) for aerobic culture and thio-glycolate broth for anaerobic bacterial culture. Paraffin oil was poured on to the surface of anaerobic sample to create an anaerobic condition. All these samples were preserved at $-20^{\circ} \mathrm{C}$ until culture.

\section{Culture of organisms}

For the growth of aerobic bacteria the samples were plated on nutrient agar, McConkey agar and mannitol Salt agar media and incubated at $37^{\circ} \mathrm{C}$ for 48 hours. On the other hand for anaerobic bacterial growth, anaerobic incubator was used. In the case of anaerobic bacteria, nutrient agar and blood agar media were used. All the procedure was conducted at $37{ }^{\circ} \mathrm{C}$ temperature for 48 hours.

\section{Isolation and identification of bacteria}

The selected colonies of bacteria were identified on the basis of their colony characteristics, Gram stain, hemolytic properties and growth on selective media. After presumptive identification, the culture specific biochemical tests were performed.

\section{Statistical Analysis}

All data obtained were computerized by MS Excel and subjected to standard statistical analysis. STATA/IC - 11 were done for $p$ value. Differences were considered to be significant at $5 \%$ level of significance.

\section{Results and Discussion}

Different types of reproductive diseases or disorders viz. endometritis, pyometra, cervicitis, abortion, vaginitis, maggot infestation in vagina and bloody discharge were recorded during sample collection. The first four types were considered as 'uterine infection' due to presence of pus. A total of 109 cows selected in

Table 1. Distribution of animals according to breed, age and parity

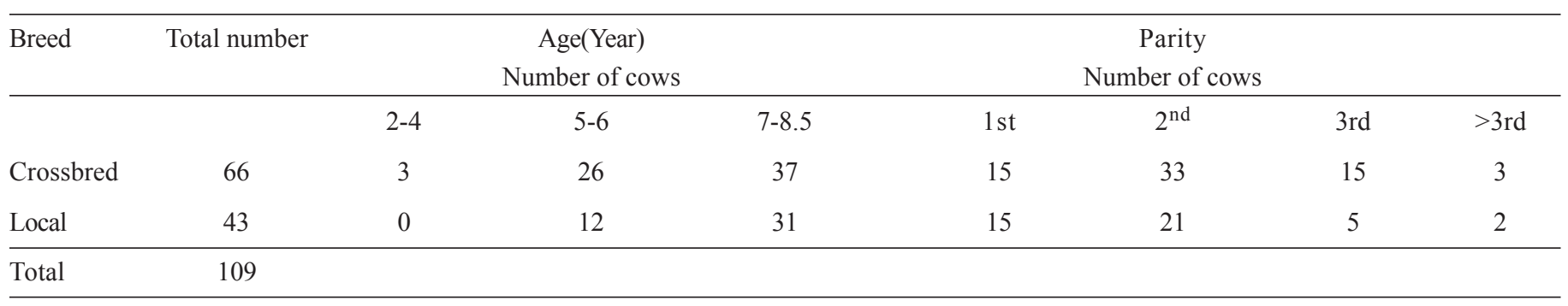


this study, 33 had symptoms of different reproductive diseases, whereas 76 were apparently healthy. The prevalence of uterine infection was found in a total of 24 cows (Table 2). Nine others showed reproductive diseases of different types. Variation in the occurrence of uterine infection may be due to the influence of age and parity as well as breed of the sire ${ }^{11,12}$. The bloody discharge was not considered as uterine infection because no other sign was observed except blood in the sample. It could be due to genital injury during collection of sample. Vaginitis (3.03\%) and maggot infestation (10\%) were also observed in this study. Among different reproductive disorders, the endometritis were highest $(33.33 \%)$ followed by pyometra $(18.18 \%)$, cervicitis $(15.15 \%)$ and abortion (6.06\%) (Table 2).

The overall prevalence of endometritis during postpartam period in dairy cows may vary in different report ${ }^{13,14}$. Clinical endometritis is one of the most common disorders in dairy cows, causing decreased fertility and large economic loss ${ }^{15}$. Another very common uterine infection of cows is pyometra, which accounted for $18.18 \%$ of total reproductive disorder in this study. Other studies by Tadesse (1999) ${ }^{16}$ and Oumermohammed (2003) ${ }^{17}$ reported even higher percentage of pyometral cases in cows in their research. The prevalence of abortion in this study was $6.06 \%$ which is similar to the study of Shiferaw (1999) ${ }^{18}$ and Kassahun $(2003)^{19}$. On the other hand, Oumermohammed (2003) ${ }^{17}$ and Durrani $(2009)^{20}$ observed $3.19 \%$ and $3.2 \%$ of abortion cases in cows. In this study, abortion found only in crossbred cows. It could be due to contamination of semen with Brucella organism during artificial insemination.
Table 3 shows the correlation between age and reproductive diseases. The highest percentages of reproductive diseases found in cows of 7-8.5 years old followed by the age of 5-6 years. The cows of 2-4 years old had lowest percentages of reproductive diseases. Among the diseased cows, the occurrence rate was more than $71 \%$ in crossbred and $91 \%$ in local cows of higher age group and $23.8 \%$ in crossbred and $8.3 \%$ local in cows of 5-6 years old. It is also observed that on average crossbred are most susceptible (63.63\%) to reproductive diseases than the local cows (36.37\%). This finding has similarities with other studies stated that crossbred cattle are more susceptible to diseases than indigenous cattle ${ }^{21}$. Mukasa-Mugerwa (1991) $)^{22}$ conducted the study in crossbred and local cows of more than six years old and stated that significantly higher prevalence rate of reproductive problems in crossbred animals than indigenous zebu may be due to the fact that crossbred are less adapted to tropical conditions of high temperature and humidity, disease and low feed quality than zebu cattle making them more susceptible than indigenous zebu. Age and parity had significant effect on the prevalence of reproductive health problems, where increasing of age increases the susceptibility of uterine disease in cows which may be due to decreasing immunity, increasing microbial load, nutritional insufficiency, and increasing reproductive disorders ${ }^{23-26}$. Increasing age generally indicates the increasing number of parity. In this study it is found that increasing age increasing the prevalence of reproductive problems in cows, its may due to more parity give chance to entrance of microorganisms and more scope of contamination during and after parturition.

Table 2. Incidence of reproductive diseases or disorders $(n=33)$

\begin{tabular}{lcccc}
\hline Diseases & Crossbred & Local & \% Repr. diseases & $\begin{array}{c}\text { \% Uterine infection among } \\
\text { reproductive diseases }\end{array}$ \\
\hline Endrometritis (UI) & 5 & 6 & $33.33(11)$ & $33.33(11)$ \\
Pyometra (UI) & 4 & 2 & $18.18(6)$ & $18.18(6)$ \\
Cervicitis with UI & 4 & 1 & $15.15(5)$ & $15.15(5)$ \\
Abortion (UI) & 2 & 0 & $6.06(2)$ & $6.06(2)$ \\
Vaginitis & 0 & 1 & $3.03(1)$ & - \\
Maggot in Vagina & 1 & 2 & $10.00(3)$ & - \\
Bloody discharge & 5 & 0 & $15.15(5)$ & $72.72(24)$ \\
\hline Total & 21 & 12 & $100(33)$ & 22.02 \\
\hline
\end{tabular}

Table 3. Reproductive diseases in different age in cows

\begin{tabular}{|c|c|c|c|c|}
\hline \multirow[t]{3}{*}{ Breed } & \multirow{2}{*}{\multicolumn{3}{|c|}{$\begin{array}{c}\text { Age (year) } \\
\% \text { Reproductive diseases }\end{array}$}} & \multirow[t]{3}{*}{$\%(n=33)$} \\
\hline & & & & \\
\hline & $2-4$ & $5-6$ & $7-8.5$ & \\
\hline Local & - & $8.3(1)$ & 91.7 (11) & $36.37(12)$ \\
\hline
\end{tabular}


Uterine infection was observed in 17 cows $(n=89)$ those were inseminated artificially and in 7 cows $(n=20)$ inseminated naturally. Among the apparently diseased cows were $52 \%$ and $21.21 \%$ infection was found in those inseminated artificially and naturally, respectively. The result is indicated that prevalence of uterine infection (15.6\%) is higher in case of artificial insemination when compared to natural insemination (6.42\%) (Table 4$)$. The possible cause may be due to tendency on artificial insemination in crossbred cow and the organisms transmit during insemination.

The organisms including Fusobacterium spp, Streptococcus spp, Pseudomonas spp Staphylococcus spp, Actinomyces spp, Haemophilus spp, Micrococcus spp, Bacteroides spp, Escherichia coli, Pasteurella spp, Diplococcus spp, Peptococcus spp, Klebsiella spp, Enterobacter spp, Bacillus spp, Nocardia spp, Clostredium spp, Salmonella spp and Proteus spp were isolated from uterine sample. Table 5 shows the list of bacteria found in both diseased and non diseased samples, only Nocardia spp and Clostridium spp were absent in diseased and Bacillus spp and Salmonella spp were absent in non diseased sample. A significant number of bacteria were identified from diseased samples and they were Fusobacterium $\operatorname{spp} 16(48.5 \%)(\mathrm{p}=0.000)$, Actinomyces spp $11(33.33 \%)(\mathrm{p}=0.001), E$. coli $11(33.33 \%)(\mathrm{p}=0.002)$, Pseudomonas spp $11(33.33 \%)(\mathrm{p}=0.003)$ and Haemophilus spp $11(33.33 \%)(\mathrm{p}=0.001)$ (Table 5). The isolated of Pseudomonas and gram negative minute rod shaped bacteria were obtained only from repeat breeder cows with mucopurulent uterine discharges ${ }^{27}$. Actinomyces pyogenes is considered to be a major pathogen of the reproductive tract among others and Hemophilus spp is well known to cause uterine infection. Bacterial causes are most important behind endometritis in cows. Arcanobacterium, Staphylococcus, Streptococcus, E. coli and Klebsiella spp are found to be associated with endometritis in cows ${ }^{7}$. Predominantly identified bacteria in this study were Staphylococcus spp and Streptococcus spp accounting 10 (33\%) and 9 (27.3\%), respectively. Presence of other bacteria were between the range of 1 (3.00\%) to 6 (18.20\%) (Table 5). In a study by Gani $(2008)^{27}$ showed that Staphylococcus spp was predominant (37.8\%), followed by $E$. coli (29.7\%), Pseudomonas (18.9\%) while Gram negative minute rod shaped bacteria was found in $24.3 \%$ of cases in repeat breeder cows.

In non-diseased cases, the highest number of samples was positive for Bacteroied spp. (13.20\%). Streptococcus spp. was found in $10.4 \%$ of the cases. The similar number of Diplococcai spp and Micrococcai spp were observed in $9.2 \%$ of the cases.

Table 4. Type of insemination and uterine infection

\begin{tabular}{lccc}
\hline Type of insemination & Uterine infection & \% Diseased cows $(\mathrm{n}=33)$ & \% All cows $(\mathrm{N}=109)$ \\
\hline AI $(\mathrm{n}=89)$ & 17 & 52.00 & 15.60 \\
NS $(\mathrm{n}=20)$ & 7 & 21.21 & 6.42 \\
\hline
\end{tabular}

Table 5. Isolation and identification of microorganisms from uterine samples in cow

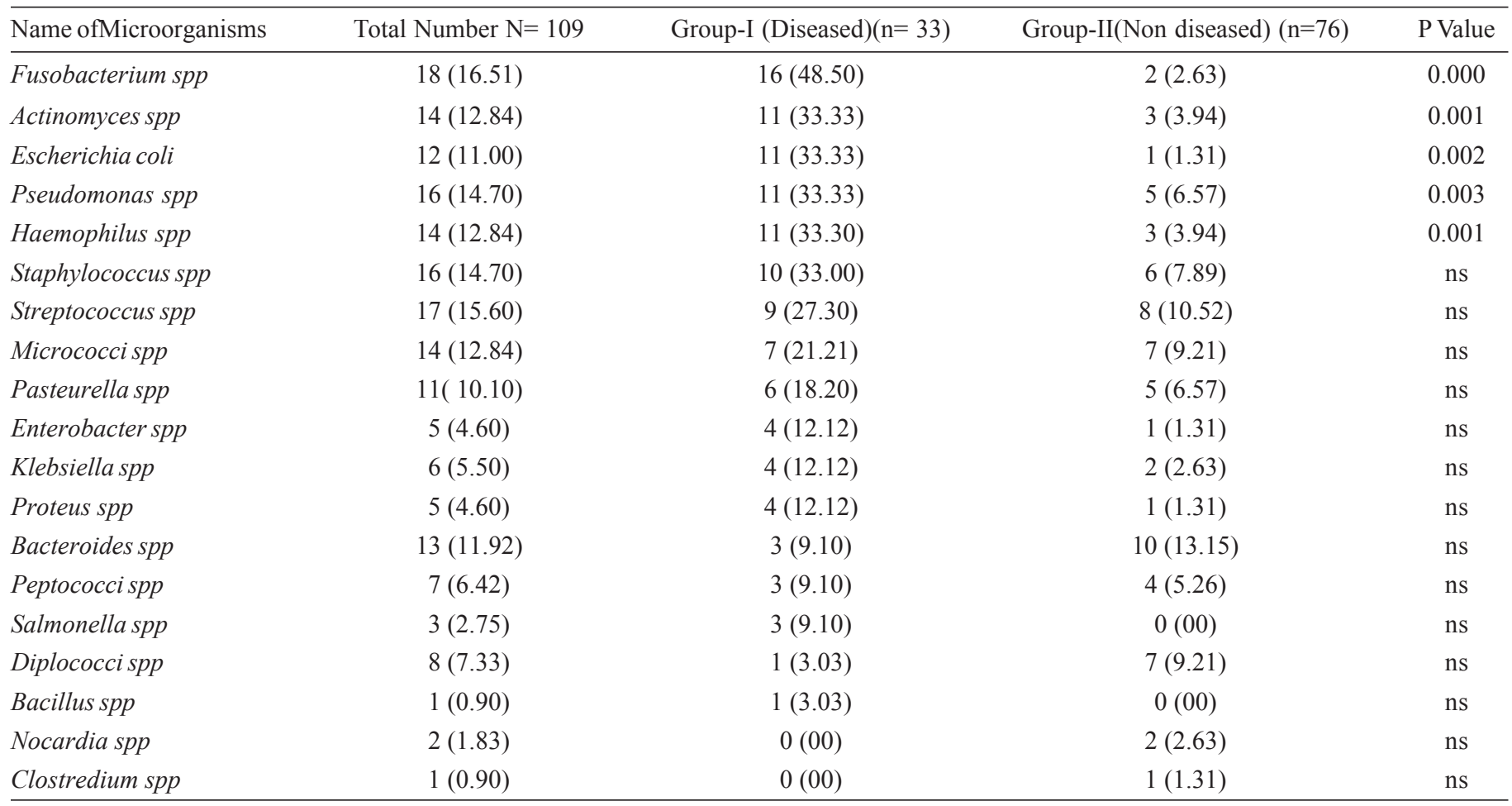

$\mathrm{p}=0.000,0.001,0.002,0.003$ and 0.001 is statistically significant. $\mathrm{ns}=$ not significant 
However, on average, the highest numbers of organisms were found in diseased samples and most of those bacteria are pathogenic. About $60 \%$ of the identified bacteria from uterus commonly found in repeat breeders as well as from diseased animals and the frequency of the isolates were much higher than that of normal cows ${ }^{26,27}$. Uterine disease is commonly associated with Escherichia coli, Arcanobacterium pyogenes, Fusobacterium necrophorum and Prevotella species. Indeed, A. pyogenes, $F$. necrophorum, Prevotella and Streptococcus species have been shown to act synergistically to enhance the likelihood of uterine disease $^{28}$. In another study by Erin $(2005)^{2}$, showed that the most common and economically important bacteria for uterine infection are Actinomyces, Escherichia coli, Fusobacterium, Pasteurella, Pseudomonas and Staphylococcus. From the above discussion it is easily understood that most of the endometrial and pyogenic cases and or uterine infections were caused by Fusobacterium spp, Actinomyces spp, E. coli, Pseudomonas spp and Haemophilus spp. Staphylococcai spp, Streptococcus spp, pasteurella spp, Enterobacter spp, Klebsiella spp and Proteus spp.

\section{Conclusion}

In conclusion, the prevalence of uterine infection is higher in crossbred than local cows. Cows were inseminated artificially suffered more in uterine infection than inseminated naturally. Different pathogenic, non pathogenic, facultative, aerobic and anaerobic bacteria were identified from uterus in dairy cows. However, higher percentages of bacteria were found in diseased samples than non diseased samples. It also observed that older cows are most susceptible to different reproductive disorders and uterine infection than younger.

\section{Acknowledgement}

The authors are grateful to CVASU for funding and to BLRI, Savar, Dhaka, Bangladesh for supporting the lab facilities to do all the tests for this research. The authors are also thankful to all the persons involved in this study, especially to the dairy farmers, AI technicians for providing the facilities and necessary information during the study.

\section{References}

1. Sheldon IM and Dobson H. 2004. Postpartum uterine health in cattle. Animal Repro Sci. 82-83: 295-306.

2. Erin JW, Debora PF, Dirk UP, Gary CWE, David EN, Hilary D and Sheldon IM. 2005. Clinical evaluation of postpartum vaginal mucus reflects uterine bacterial infection and the immune response in cattle. Theriogenology. 63:102-117

3. Opsomer G, Mijtem P, Coryn M and Kruif AD. 1996. Postpartum anoestrus in dairy cows: A Review. Vet Quart. 18 (2): 68-75.

4. Sirohi NS, Monga DP, Knar SK. 1989. Microbiological studies on some reproductive disorders of cattle. Indian J Animal Sci. 59 (5): 537-541.

5. Singia VK, Singh G, Dwivedi PN and Sharma RD. 1993. In vivo evaluation of drug sensitivity pattern of bacterial isolates in repeatbreeder cows. Indian J Animal Sci. 63 (4): 425-426.

6. Singh NP, Chaturvedi VK and Singh DP. 1996. Bacteriological studies on repeat breeder bovines. Indian Veterinary Journal. 73 (4): $462-$ 463.

7. Foldi J, Kulcsar M, Pecsi A, Huyghe B, de Sa C, Lohuis JA, Cox P and Huszenicza G. 2006. Bacterial complications of postpartum uterine involution in cattle. Animal Repro Sciences 96: 265-281.
8. Elliott L, McMahon KJ, Gler HT and Marion GB. 1968. Uterus of the cow after parturition: Bacterial content. American J Vet Res. 29: 77.

9. Rahman A, Rahman A, Rahman H and Ahmed MU. 1996. Anaestrus and repeat breeding problems in indigenous cattle in Bangladesh. Trop Animal Health Pro. 7: 605-609.

10. Gilbert RO, Shin ST, Guard CL, Erb HN and Frajblat M. 2005. Prevalence of endometritis and its effects on reproductive performance of dairy cows. Theriogenology. 64: 1879-1888.

11. Morrow DA. 1986. In: Current therapy in theriogenology. Diagnosis, treatment and prevention of reproductive diseases in animals. W.B. Soundars Co. Philadelphia. pp 322-571.

12. Noakes DE. 1986. In: Fertility and obstetrics in cattle. Black Well. Sci. pub, UK. pp 28-30.

13. Gautam G, Nakao T, Yusuf M and Koike K. 2009. Prevalence of endometritis during the postpartum period and its impact on subsequent reproductive performance in two Japanese dairy herds. Animal Repro Sci. 116(3-4):175-87.

14. Ill H K and Hyun-Gu K. 2003. Risk factors for postpartum endometritis and the effect of endometritis on reproductive performance in dairy cows in Korea. $J$ Repro dev. 49: 6.

15. LeBlanc SJ. 2008. Postpartum uterine disease and dairy herd reproductive performance: A review. Vet J. 176: 102- 114.

16. Tadesse M. 1999. Major post partum reproductive problems in Holetta research station and smallholders' dairy cattle. DVM thesis. Faculty of Veterinary Medicine, Addis Ababa University, Debre Zeit, Ethiopia.

17. Oumermohammed E. 2003. Study on major reproductive health problems of small holder diary farms in and around Kombolcha. DVM thesis. Faculty of Veterinary Medicine, Addis Ababa University, Debre Zeit, Ethiopia.

18. Shiferaw Y. 1999. Fertility status of dairy cows under different production systems in Holetta central Highland of Ethiopia. MSc Thesis, Addis Ababa University and Freie Universitat Berlin, FVM, Debre Zeit, Ethiopia.

19. Kassahun M. 2003. Major clinical reproductive problems of small holder dairy cows in and around Awassa. DVM thesis. Faculty of Veterinary Medicine, Addis Ababa University, Debre Zeit, Ethiopia.

20. Durrani AZ and Kamal N. 2009. Prevalence of genital tract problems in clinical cases of various species of animals. The J Animal Plant Sciences. 19(3): 160-162

21. Ruder CA, Sasser RG, Williams RJ, Fly JK, Bull RC and Butler JE. 1990. Uterine infections in the postpartum cow, possible synergistic effects of Fusobacterium necrophorum and Corynebacterium pyogenes. Theriogenology. 15: 573-780.

22. Mukasa-Mugerwa E, Azage T, Tafese M and Teklu Y. 1991. Reproductive efficiency of Bos indicus (Zebu) cows under artificial insemination. Animal Repro Sciences. 24: 63-72.

23. Gizaw Y, Bekana M and Abayneh T. 2007. Major reproductive health problems in smallholder dairy production in and around Nazareth town, Central Ethiopia. Priory Medical Journal Online.

24. Herath S, Dobson H, Bryant CE and Sheldon IM. 2006. Use of the cow as a large animal model of uterine infection and immunity. $J$ Repro Immunol. 69: 13-22.

25. Shamsuddin M, Bhuyan MMU, Sikder TK, Sugulle AH, Chandra PK and Alam MGS. 2001. Constraints limiting the efficiency of artificial insemination of cattle in Bangladesh. In: International Atomic Energy Agency. 1220: pp 9-27.

26. Singh M and Pant HC. 1999. Factors associated with repeat breeding in Himachal Pradesh. Indian Vet J. 76 (6): 522-523.

27. Gani MO, Amin MM, Alam MGS, Kayesh MEH, Karim MR, Samad MA and Islam MR. 2008. Bacterial flora associated with repeat breeding and uterine infections in dairy cows. Bang $J$ Vet Medicine. 6(1): 79-86.

28. Sheldon IM, Williams EJ, Miller ANA, Nash DM and Herath S. 2008. Uterine diseases in cattle after parturition. Vet J. 176(1-3): 115-121. 